Except for the above criticism we have nothing but praise to give, and we have no hesitation in recommending the book to those interested in ophthalmic operations.

\title{
CORRESPONDENCE
}

\section{POSTPONEMENT OF THE INTERNATIONAL CONGRESS, 1925.}

The following communication has been sent to us by the General Secretary of the Société française d'Ophtalmologie requesting us to publish it.

In the May, 1924 (p. 252), number of the British Journal of Ophthalmology a communication from Professor Uhthoff (Breslau) is published concerning the proposition of the German medical corporation not to treat any French or Belgian patient. He says : "This interpretation is misleading. All that the French press has published as a general principle on the part of German doctors is nothing but a misrepresentation of a protesting and demonstrative measure taken by German medical men at the time of the "Ruhr Invasion.' "'

The French ophthalmologists have had nothing to interpret. They only spoke of a decision which was published in the German press. Here are two original trustworthy papers about which no mistake is possible.

First of all, the great medical journal Münchener Medizinische Wochenschrift, February 16, has published a paper from Munich, February 14, 1923, in which is said:

"The German doctors have placed themselves, too, on the lines facing the disturbers of peace. Two great medical associations the "Arztevereinbund" and the "Hartmannbund" beg of the German doctors to act on our side against the French and Belgians who have disobeyed the rules and laws of humanity in the struggle. Let us refuse any kind of assistance to Frenchmen and Belgians. Neither advice nor help before the occupied regions get free. ... With such enemies, no consideration; using all the weapons we have yet, is a duty for every German. 
"Therefore, we join our colleagues and we claim neither advice nor help to a Frenchman or to a Belgian as long as the invaders have not left the German land."

Secondly, in the paper "Die Einheit des Wollens," February, published in the Vossische Zeitung," February 11, 1923, Mr. Georg Bernhard writes: "The 'Arztevereinbund' and the 'Hartmannbund' appeal to the doctors to refuse any help to Frenchmen and Belgians as long as the territories are not free from occupation."

These statements are clear enough; we need not speak any more about the question. The discussion is over; our quotation puts a stop to the quarrel.

To the Editor of The British Journal of Ophthalmology

Dear Sir,-I see in the British Journal of Ophthalmology, July, 1924, your notice on the scientific museum exhibits, and you state on page 329 that I showed "Autochrome Photographs of Diseases of the Eye." The photographs I showed were Stereoscopic, and this is the point I wanted to emphasize, as they are much more useful for teaching students than the ordinary ones, as they give a much better idea of the case than the ordinary photograph.

Yours truly,

John Rowan.

\section{NOTES}

Appointments

Dr. W. Oliver LODGE has been appointed consulting Ophthalmologist to the Bradford Corporation.

Mr. J. R. Rolston has been appointed consulting Ophthalmic Surgeon to the South Devon and East Cornwall Hospital, Plymouth.

Mr. R. E. BICKERTON has been appointed medical Referee under the Workmen's Compensation Act, 1906, for the districts of Ashford, Canterbury, Faversham, Tenterden and Cranbrook, Deal, Dover, Folkestone, Hythe, Margate, Ramsgate, Rochester, Sheerness and Sittingbourne County Courts (Circuit No. 40) for ophthalmic cases. 